\title{
A ACADEMIA EM TEMPOS DE PANDEMIA
}

A pandemia de Covid-19 deixou claro que o mundo não está exatamente dividido em países desenvolvidos, países emergentes e países pobres. Em todas as nações do planeta tem sido possível observar a fragilidade de inúmeros grupos sociais, que em seus próprios territórios nacionais, enfrentam as agruras provocadas pelo novo coronavírus.

Desse modo, tão logo instalou-se enquanto indelével realidade sanitária, a Covid-19 tornou-se foco de discussão em diferentes grupos acadêmicos do mundo todo, particularmente aqueles que não lidam com a doença diretamente. A principal questão que tem perturbado investigadores nas áreas de Ciências Humanas parece ser a de como produzir pensamento crítico e relevante diante dos números crescentes e impactantes de contaminados e de óbitos em todas as regiões do planeta. Como persistir conduzindo pesquisas em nossa área, que parece não poder contribuir de imediato para auxiliar na solução desse problema mundial e diante da expectativa do retorno do vírus e do consequente aumento de casos de contaminação em regiões nas quais a disseminação da doença está, aparentemente, sob controle? São inúmeros os debates realizados em transmissões ao vivo nas plataformas de vídeo, cujas gravações circularam pelas redes sociais, e em textos publicados em jornais e editoras que tornaram gratuitos o acesso aos seus conteúdos. Pensadores, filósofos ou não, como Byung-Chul Han, Miguel Nicolelis, Giorgio Agamben, Peter Sloterdijk, Jacques Rancière, Judith Butler, Antonio Negri, Vladimir Safatle, Natália Pasternak, Jérôme Baschet, Paul B. Preciado, Débora Danowski, Jean-Luc Nancy, José Gil, Emanuele Coccia, Eliane Brum, Eyal Weizman, Silvia Federici, Philippe Descola, Donna Haraway, Eduardo Viveiros de Castro são alguns dos que tornaram públicas experiências da pandemia a partir de suas áreas de atuação acadêmica, instigando-nos a pensar coletivamente sobre esse novíssimo flagelo humano.

Para alguns, o gesto maior de resistência é a militância política ou o ativismo solidário, que procura centrar esforços na ação em favor das populações em maior situação de risco frente à doença. Para outros, a escrita acadêmica é em si mesma uma forma de resistência, um modo de fazer o pensamento permanecer, de mostrar a resiliência e a potência que o pensamento tem de nos forçar a pensar, como disse Gilles Deleuze. Uma forma de usar o pensamento crítico como ato que fortalece o presente e prepara para o futuro, ainda que incerto.

A equipe de editores de Prometeica optou por essa segunda vertente e foi extremamente interessante perceber, ao reler os textos para a redação deste editorial, como os temas escolhidos para compor esta edição coincidentemente tangenciam ou até mesmo lidam diretamente com questões, conceitos e noções que nos são caros neste momento. Cada artigo ganhou uma nova significação pelo olhar de alguém que está, como muitos colegas da academia, mergulhada em lucubrações sobre o que nos aguarda a partir dessa prática nova que se impôs a todos, a do distanciamento social, a única prática realmente efetiva e definitivamente vinculada a uma ação de resistência, segundo Ghassan Hage.

Assim, curiosamente, esta edição número 21 apresenta textos a partir dos quais é possível pensar essa experiência única, intensa e comum a todos nós, provenientes desse mau encontro com o novo coronavírus. Experiências advindas do isolamento social, da perda, do luto, da solidariedade, do medo, da revolta face a ações governamentais ineficazes, contraditórias ou mesmo irresponsáveis.

Na abordagem realizada por Marcus Alves temos o interessante debate acerca da noção de tempo em Santo Agostinho e seu delineamento como tempo psicológico e social no cristianismo, a partir de seu esforço epistemológico para separar o tempo entendido como a eternidade divina do tempo percebido como duração humana. 
Omar Alejandro Murad realiza uma análise metalinguística da noção de vítima a partir da visada interpretativa de Rene Girard, explorando a genealogia do termo e de seu uso desde as narrativas míticas até sua inserção nos discursos contemporâneos que organizam intervenções públicas coletivas e individuais acerca da figura da vítima.

Letícia Helena Fernandes de Oliveira explora as relações entre dois cursos seminais de Kant: o curso de Physische Geographie e sua Anthropologie, defendendo a importância da primeira para o desenvolvimento da segunda, bem como a relação dessas obras com a proposta kantiana referente à importância de ambas as experiências, uma vinculada à natureza e outra ao homem, para o conhecimento do mundo (Weltkenntniß).

Em seu artigo sobre o ensino de línguas, José María Gil investiga como o estudo de textos literários pode ser o eixo organizador do ensino da língua materna, uma vez que parece favorecer muito o desenvolvimento das competências de leitura e de comunicação.

Carlos Puig, por sua vez, realiza uma análise das noções de beleza e verdade nas Ciências Naturais, em especial na linguagem matemática, a partir do pensamento do físico alemão Werner Heisenberg (1901-1976). Puig explicita a relação estreita que o físico percebia entre a beleza dos fenômenos naturais e a beleza da ciência, enquanto linguagem matemática que busca a verdade, bem como o modo pelo qual o físico alemão recorre aos filósofos da Antiguidade e suas definições, para defender seu ponto de vista.

Explorando a filosofia política de Alasdair MacIntyre, Rivas Pedro discute as teses do filósofo acerca do bem comum, a partir de um conjunto de palestras do autor de 1994, algumas consideradas inéditas, com o objetivo de explorar a ideia de interesse público como conceito que estrutura as comunidades políticas modernas.

Ainda nesta edição, Nicolás Martínez Saez conversa com o medievalista Ángel Molina Molina sobre o surgimento dos jogos e outras formas de recreação na Idade Média e os paralelos possíveis com o papel do jogo no desenvolvimento da Ciência e da Filosofia modernas.

Por fim, a seção Resenhas conta com a colaboração de Emilio Alochis, que nos brinda com uma exposição cuidadosamente comentada de Los bordes de la ficción (2019), um conjunto de ensaios de Jacques Rancière sobre as relações entre escrita literária e a realidade a partir de obras de ficção e de não-ficção, enquanto Elías Bravo apresenta com detalhes preciosos o livro Wittgenstein (2020), resultado de um minucioso trabalho de investigação de Federico Penelas sobre o filósofo austríaco.

Apesar de reconhecermos os tempos difíceis que todos enfrentamos, é com alegria e muita esperança por dias melhores que entregamos aos leitores assíduos ou aos novos interessados em Prometeica mais uma edição.

Este foi o primeiro número de Prometeica editado durante a quarentena provocada pela pandemia de Covid-19. Esperamos que seja, também, o único, e que em breve as vidas de todas as pessoas em todo o mundo possa retornar de algum modo ao feliz hábito do convívio social amiudado que faz da nossa existência algo tão raro e precioso.

Estejam bem e aproveitem a leitura.

Cristina Bonfiglioli Editora Adjunta 